Alexandre Henrique Lucchetti

Interbank network and regulation policies: An analysis through agent-based simulations with adaptive learning

Brasília 

Alexandre Henrique Lucchetti

\title{
Interbank network and regulation policies: An analysis through agent-based simulations with adaptive learning
}

Dissertação apresentada ao Programa de Mestrado em Economia da Universidade de Brasília como requisito à obtenção do título de Mestre em Ciências Econômicas.

\author{
Universidade de Brasília \\ Faculdade de Economia, Administração e Contabilidade \\ Departamento de Economia
}

Orientador: Prof. Daniel Oliveira Cajueiro, PhD

Brasília

2016 



\title{
Interbank network and regulation policies: An analysis through agent-based simulations with adaptive learning
}

\author{
Dissertação apresentada ao Programa de \\ Mestrado em Economia da Universidade de \\ Brasília como requisito à obtenção do título \\ de Mestre em Ciências Econômicas.
}

Trabalho aprovado. Brasília, 27 de junho de 2016:

Prof. Daniel Oliveira Cajueiro, PhD

Universidade de Brasília

Orientador

Prof. Vinicius Amorim Sobreiro, PhD

Universidade de Brasília

Prof. Herbert Kimura, PhD

Universidade de Brasília

Brasília

2016 



\section{Resumo}

Foi usado o modelo baseado em agentes de Barroso (2014) e Lima (2014) para estudar os impactos de uma ampla gama de políticas regulatórias sobre o setor bancário. Esse modelo se baseia em uma versão iterada do modelo de Diamond e Dybvig (1983) e lança mão do esquema de aprendizagem experience-weighted attraction de Camerer e Ho (1999) para modelar o aprendizado adaptativo dos agentes. Dessa forma, conseguimos capturar não somente os impactos diretos da regulação, mas também os que ocorrem através da alteração das estratégias adaptativas dos agentes. Os resultados mostram que uma câmara de compensação interbancária é um bom instrumento para fazer frente ao risco de contágio; as recomendações dos Acordos de Basiléia são efetivas na redução do risco de falência dos bancos; e a adoção de um seguro de depósito pode ser adequada para evitar corridas bancárias. Entretanto, nós também mostramos que essas políticas têm suas desvantagens, podendo tanto reduzir a atividade bancária quanto estimular o risco moral.

Palavras-chave: Rede interbancária, regulação, modelo baseado em agentes, aprendizado adaptativo. 



\section{Abstract}

We use the agent-based model of Barroso (2014) and Lima (2014) to study the impacts of a broad range of regulation policies over the banking system. The model builds on an iterated version of the Diamond and Dybvig (1983) framework and resorts to the experience-weighted attraction learning scheme of Camerer and Ho (1999) to model agents' adaptive learning. Thereby, we can capture not only the direct impacts of regulation policies, but also the ones that take part through shifting agents' adaptive strategies. Our results show that an interbank clearinghouse is a good instrument to face the risk of contagion; the regulatory guidelines of the Basel Accords are effective in reducing the risk of bank failure; and the adoption of a deposit insurance can be adequate to avoid bank runs. However, we also show that these policies have drawbacks, and can either reduce bank activity or stimulate moral hazard.

Keywords: Interbank network, regulation, agent-based model, adaptive learning. 



\section{List of figures}

Figure 1 - Bank interest spread experiment results . . . . . . . . . . . . . . 42

Figure 2 - Clearinghouse experiment results . . . . . . . . . . . . . . 43

Figure 3 - Basel Accord experiment results . . . . . . . . . . . . . . 46

Figure 4 - Deposit insurance experiment results . . . . . . . . . . . . . . . 47 



\section{List of tables}

Table 1 - Banks' liabilities . . . . . . . . . . . . . . 26

Table 2 - Banks' assets . . . . . . . . . . . . . . . 27

Table 3 - Learning parameters . . . . . . . . . . . . . 38

Table 4 - Benchmark parameters . . . . . . . . . . . . . 39

Table 5 - Bank interest spread experiment parameters . . . . . . . . . . . 40

Table 6 - Basel Accord experiment parameters . . . . . . . . . . . . . 45 



\section{List of abbreviations}

$\begin{array}{ll}\text { BIS } & \text { Bank for International Settlements } \\ \text { CAR } & \text { Capital Adequacy Ratio } \\ \text { EWA } & \text { Experience-Weighted Attraction } \\ \text { LGD } & \text { Loss Given Default } \\ \text { PD } & \text { Probability of Default } \\ \text { ROE } & \text { Return on Equity } \\ \text { RWA } & \text { Risk-Weighted Assets }\end{array}$





\section{List of symbols}

\begin{tabular}{ll}
$A_{i}^{j}(t)$ & Attraction update function of strategy $j$ for agent $i$ in $t$ \\
$\phi$ & Attraction depreciation \\
$\delta$ & Forgone payoffs' weight \\
$N_{i}(t)$ & Experience of agent $i$ in $t$ \\
$\rho$ & Depreciation of experience \\
$\lambda$ & Sensitivity to attractions \\
$K$ & Bank's Capital \\
$D$ & Deposits \\
$i_{d}$ & Deposit interest rate \\
$I B / I L$ & Interbank Loans \\
$i_{i}$ & Interbank interest rate \\
$C B$ & Central bank loans \\
$i_{c b}$ & Central bank loan interest rate \\
$L$ & Liquid assets \\
$R$ & Real sector loans \\
$F_{L}$ & Set of firms with loans in bank $b$ \\
$F_{b}$ & Real sector loans return \\
$\delta_{L}$ & Ratio of capital to total liability \\
\hline & Ratio of liquid assets to total assets \\
\hline & Profit assets or total liabilities \\
\hline &
\end{tabular}


imp Probability of impatient depositor

$\gamma \quad$ Depositor's risk tolerance

U Depositor's utility

$c_{d}^{t} \quad$ Depositor's consumption in $t$

$g_{b} \quad$ Collateral provided by bank $b$

ls $\quad$ Liquidity shortage

G Total collateral

$\delta_{I} \quad$ Depreciation of insolvent bank's assets 


\section{Contents}

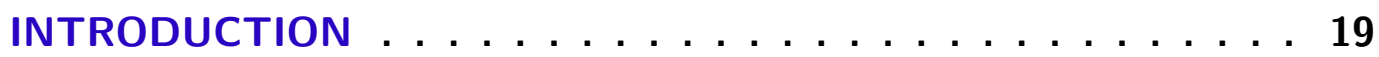

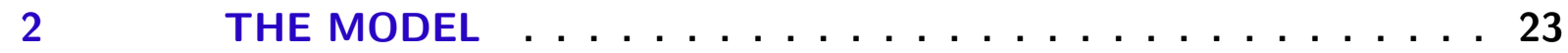

$2.1 \quad$ Learning . . . . . . . . . . . . . . . . . . . . . 24

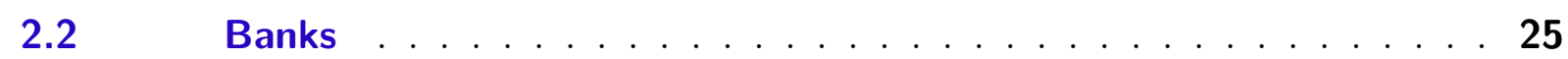

2.2.1 Balance sheet . . . . . . . . . . . . . . . . . . 25

$2.2 .2 \quad$ Bank strategy . . . . . . . . . . . . . . . . 27

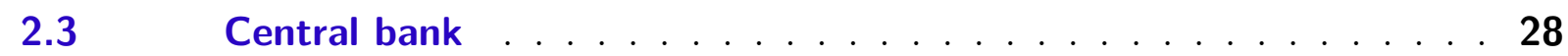

2.3.1 Central bank strategy . . . . . . . . . . . . . . . . . . . . . . . . 29

2.4 Depositors . . . . . . . . . . . . . . . . . . . . . 29

2.4.1 Depositor strategy $\ldots \ldots \ldots \ldots$

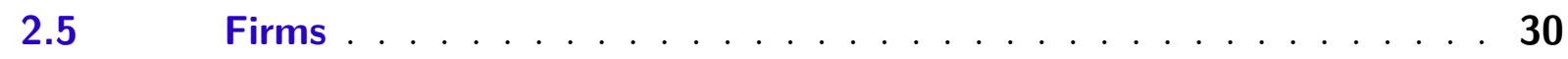

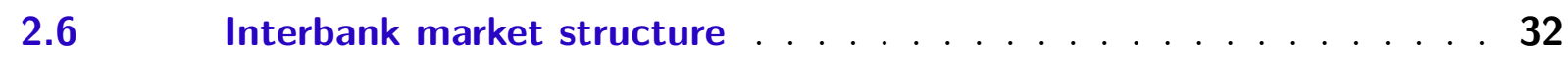

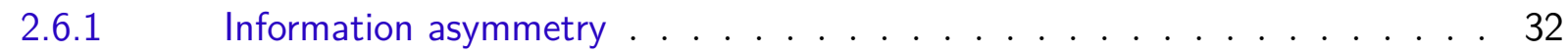

$2.6 .2 \quad$ Clearinghouse . . . . . . . . . . . . . . . . . 33

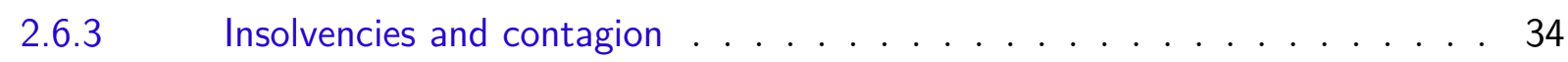

$2.7 \quad$ Events within cycles $\ldots \ldots \ldots \ldots \ldots \ldots$

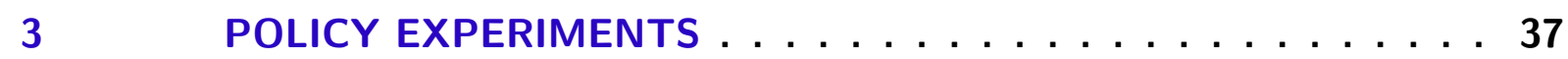

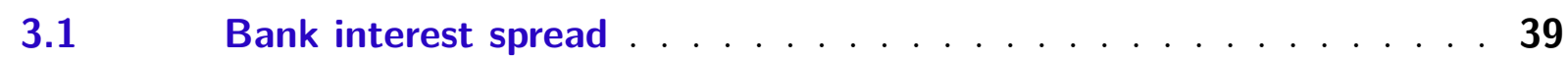

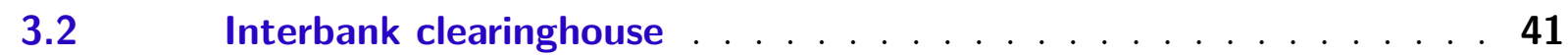

3.3 Basel Accord policy framework . . . . . . . . . . . . . . . 44

3.4 Deposit insurance . . . . . . . . . . . . . . 46

$4 \quad$ CONCLUSION $\ldots \ldots \ldots \ldots \ldots \ldots$

BIBLIOGRAPHY $\ldots \ldots \ldots \ldots \ldots \ldots \ldots \ldots$ 



\section{Introduction}

Recurring financial crises all over the world highlight the importance of accurate regulation to maintain stability. In order for policymakers to determine the appropriate measures for each situation, it is essential to understand the increasingly complex arrangements of financial networks. With that in mind, and focusing on the banking sector, we resort to the agent-based model of Barroso (2014) and Lima (2014) to assess the outcomes of regulation policies, considering agents' strategic responses to shifts in restrictions and in the economic environment.

This model successfully captures some important results regarding banking regulation, broadly discussed in the literature. First, it shows how narrower bank interest margins are associated with greater system development and, thus, greater stability (DIETRICH; WANZENRIED; COLE, 2015; BROCK; SUAREZ, 2000). Then, it captures how the adoption of an interbank clearinghouse can reduce the risk of contagion at a low cost in terms of credit supply to the real economy. Furthermore, the clearinghouse acting as central counterparty can increase interbank activity (JAREMSKI, 2015).

Moreover, the model provides insights on the rationale of capital regulation behind the Basel Accord and how it effectively reduces the risk of bank failure. The model shows that banks' choices of economic capital resulting from their adaptive strategies lead to lower levels of capital allocation when compared to the social optimal (ELIZALDE; REPULLO, 2007), suggesting that the regulation is in fact needed. It also shows that there can be a reduction of credit supply in economies following the Basel Accord's guidelines (COSIMANO; CHAMI; BARAJAS, 2004; NACEUR; KANDIL, 2007).

Furthermore, the model also generates important results to the discussion involving deposit insurance schemes. It captures how depositors can shift the behavior of banks when monitoring their risks to avoid losses (BENNETT; HWA; KWAST, 2015). However, despite being successful in reducing the probability of bank runs, deposit insurance schemes can lead to higher risk of bank failure, once they remove depositors' incentives to enforce market discipline (DEMIRGUC-KUNT; DETRAGIACHE, 2002; BARTH; CAPRIO; LEVINE, 2004).

The economic research on banking and systemic risk has come a long way since the seminal works of Rochet and Tirole (1996), Allen and Gale (2000), Freixas, Parigi and Rochet (2000). Recent developments provide valuable insights by modeling financial systems as complex networks, so they capture the effects of various degrees of interconnection and different network topologies (EISENBERG; NOE, 2001; CAJUEIRO; TABAK; ANDRADE, 2009; UPPER, 2011; GAI; HALDANE; KAPADIA, 2011; ACEMOGLU; 
OZDAGLAR; TAHBAZ-SALEHI, 2013; GLASSERMAN; YOUNG, 2015). Following that line, one approach that has gained ground in the economic literature in recent years is the computational technique of agent-based modeling. It is a modeling tool in use by the economic research for a while now ${ }^{1}$, and provides an approach that allows models to drop some strong assumptions, often necessary to the conventional analytic approach. Maybe the most important of those assumptions is homogeneity between individuals, embodied in the figure of the representative agent. Instead, agent-based models make room for heterogeneous agents, whose local interactions - ruled by bounded rationality - cause systemic patterns to emerge (EPSTEIN, 1999; GALÁN et al., 2009; BORRILL; TESFATSION, 2011; FARMER et al., 2012). Therefore, it consist of an appropriate approach to simulate complex systems, such as interbank networks.

In the model used in this work, the interbank network is formed endogenously, as a result of banks' strategic response to liquidity shocks ${ }^{2}$. As recently used by Pouget (2007) in his study of financial markets, it resorts to the Camerer and Ho (1999) experience-weighted attraction (EWA) learning scheme to model agents' strategies. This is the main point where this model distances from the existing literature. The EWA can be seen as a general learning framework that combines aspects of reinforcement learning (ROTH; EREV, 1995) and belief-based learning (FUDENBERG; LEVINE, 1998). Other agent-based models usually adopt less general learning algorithms ${ }^{3}$ (HOMMES, 2006). Furthermore, as in Temzelides (1997), the basic structure builds on an iterated version of the Diamond and Dybvig (1983) seminal framework. Therefore, our approach addresses both, the direct effect of regulation policies over the system and the indirect effect through the adaptive behavior of agents.

The remainder of this work is organized as follows. In the next section, we will discuss in details the model used in our analysis. We first explore how the Camerer and Ho (1999) learning scheme brings important insights to agent behavior modeling. Then, we explain each agent's role and how they interact with each other. Afterwards, we discuss market structure issues and how some institutional setups are brought to the model. Finally, we conclude the section with a comprehensive analysis of the events that take place in our simulations.

Section 3 is destined to the experiments' results. We begin by discussing the effects of the bank interest margin over the banking sector activity and stability. We then proceed to regulation experiments, simulating the introduction of an interbank clearinghouse acting as central counterparty and requiring collateral and information disclosure from participants.

1 See Gallegati, Giulioni and Kichiji (2003), Goodhart, Sunirand and Tsomocos (2004), Samanidou et al. (2006), Hommes (2006), LeBaron (2006), LeBaron and Tesfatsion (2008) and Iyetomi et al. (2009).

2 For models that incorporate some sort of strategic behavior and endogenous network formation, see Erol and Vohra (2014), Babus (2013), Zawadowski (2013) and Blume et al. (2013).

3 For surveys on learning algorithms adopted in agent-based models see Hoog, Deissenberg and Teglio (2007), Kirman (2011). 
Afterwards, we simulate the adoption of Basel's regulation guidelines, represented by an experiment setup that reproduces their three regulatory pillars. The final experiment simulates the introduction of a deposit insurance scheme when depositors enforce market discipline over banks. Finally, Section 4 concludes our work. 



\section{The model}

The model used in our analysis was conceived by Barroso (2011) and enhanced by Barroso (2014) and Lima (2014). It consists of an iteration of discrete-time simulation cycles, which are based on the seminal structure of Diamond and Dybvig (1983), Allen and Gale (1998) and Allen and Gale (2000). Furthermore, it endows agents with bounded rationality, present in the ability to learn and adapt their strategies according to the Camerer and Ho (1999) learning scheme.

In this framework, banks form endogenous networks, connecting their balance sheets through interbank loans. The need to form such networks arises from banks' adaptive strategies and the presence of stochastic shocks in the economy. The framework's primary goal is to analyze the impacts of several policy designs, represented by exogenous parameters and simulation setups ${ }^{1}$.

In the simulations, we run a large number of cycles, each one divided into three time horizons, $t=0,1,2$. These time horizons and their implications to the model can be summarized as follows ${ }^{2}$ :

Period $t=0$ can be interpreted as today. This is when banks set their strategies for the cycle, i.e., they choose the initial amounts of real sector loans, liquid assets, deposits and capital.

Then, in $t=1$ - which can be understood as short-term horizon-banks face a liquidity shock, represented by the fraction of impatient depositors that withdraw their resources prematurely to anticipate their consumption. Financial institutions with liquidity shortage borrow either from other banks in the interbank market or from the central bank.

Finally, period $t=2$ can be interpreted as long-term horizon. This is when the real sector loans mature, the remaining depositors consume and the banks calculate their return on equity (ROE) in order to update their strategies through the learning scheme. In this period, banks can become insolvent due to losses in their real sector loans. They can also become insolvent due to financial contagion through the interbank market.

To add flexibility to the framework, each agent is modeled separately. In a few sections ahead, we will explore the role of each agent. Afterwards, we discuss how they interact throughout the simulation cycle and how this affects the financial system. However, we will first take a time to explore the learning scheme, as it will be crucial to the

$\overline{1}$ In some cases, policy parameters can be the result of adaptive learning from central banks, as we will see ahead.

2 For the sake of clarity, we will deepen this discussion further on this section, after each agent's role is covered. 
understanding of some of the agents' behaviors.

\subsection{Learning}

In a financial system with an endogenously formed network, the rationale behind agent's decision-making is a key aspect to determine how they will interact with each other, what patterns will arise in the system and, ultimately, what will be the outcomes of policies over the market. With that in mind, we adopt the experience-weighted attraction (EWA) learning model, proposed by Camerer and Ho (1999), to describe how agents choose strategies.

The EWA learning brings aspects of two different approaches to model agents' behavior, namely, reinforcement learning and belief-based learning. The reinforcement learning approach has in its core the law of actual effects, which claims that successful chosen strategies are more likely to be adopted again (ROTH; EREV, 1995). On the other hand, the belief-based approach, with the law of simulated effects, claims that strategies not chosen, but that would have been successful, are more likely to be adopted in the future (FUDENBERG; LEVINE, 1998).

To understand how it works, we follow Camerer and Ho (1999) and first define some notation. Let's consider the case of a game with $n$ agents indexed by $i(i=$ $1, \ldots, n)$. The strategy space of player $i, S_{i}$, consists of $m_{i}$ possible choices, i.e., $S_{i}=$ $\left\{s_{i}^{1}, s_{i}^{2}, \ldots, s_{i}^{j}, \ldots, s_{i}^{m_{i}-1}, s_{i}^{m_{i}}\right\}$. The game's strategy space is $S=S_{1} \times \ldots \times S_{n}$ and $s=\left(s_{1}, \ldots, s_{n}\right) \in S$ is a combination of strategies of all $n$ players. In turn, $s_{-i}=$ $\left(s_{1}, \ldots, s_{i-1}, s_{1+1}, \ldots, s_{n}\right)$ is the combinations of strategies of all players except player $i$. Finally, $s_{i}(t)$ is the strategy actually chosen by $i$ and $\pi_{i}\left(s_{i}(t), s_{-i}(t)\right)$ is his payoff, both in time $t^{3}$.

Agents learning through the EWA scheme adapt their choices according to the two laws mentioned earlier. In the model, this is achieved through the strategies attractions, functions that reflect the initial predisposition towards strategies, and are updated after the outcomes are realized, based on both experienced and simulated payoffs. The attraction update of strategy $j$ for agent $i$ in $t$ is:

$$
A_{i}^{j}(t)=\frac{\phi \cdot N_{i}(t-1) \cdot A_{i}^{j}(t-1)+\left[\delta+(1-\delta) \cdot I\left(s_{i}^{j}, s_{i}(t)\right)\right] \cdot \pi_{i}\left(s_{i}^{j}, s_{-i}(t)\right)}{N_{i}(t)},
$$

where $\phi$ is the parameter used to depreciate past attractions, $\delta$ is used to weight the foregone payoffs ${ }^{4}$ and $I\left(s_{i}^{j}, s_{i}(t)\right)$ is an indicator function, that assumes value of 1 when

3 In our experiments, time $t$ used here corresponds to simulation cycles.

4 Camerer and Ho (1999) point out that this is the most important parameter in EWA, that captures 
$s_{i}^{j}=s_{i}(t)$ and 0 otherwise. Finally, $N(t)$ is the measure of experience, which is updated by:

$$
N_{i}(t)=\rho \cdot N(t-1)+1
$$

with $\rho$ being the depreciation of experience. Together, $\rho$ and $\phi$ capture cognitive phenomena like forgetting and consciously discounting old experiences when the environment is changing (CAMERER; HO, 1999).

Once with the attractions, the probability of player $i$ choosing strategy $j$ is given by the logit model, also used by Pouget (2007):

$$
P_{i}^{j}(t+1)=\frac{e^{\lambda \cdot A_{i}^{j}(t)}}{\sum_{k=1}^{m_{i}} e^{\lambda \cdot A_{i}^{k}(t)}},
$$

with $\lambda$ measuring the sensitivity of players to attractions, which captures aspects of perception and motivation.

The values of parameters in the EWA learning for our agents will be discussed when we get to the experiments. The variables used as payoffs by each agent in the attraction function will be discussed in their strategy sections.

\subsection{Banks}

Banks are agents of central interest in this framework. They act as financial intermediaries, channeling funds from depositor to firms. They also connect to other banks in the interbank market and to the central bank, when needed. In each simulation, there are $B$ banks in the economy, indexed by $b$ and represented by their balance sheets.

\subsubsection{Balance sheet}

Balance sheets are designed to allow banks to fund long-term illiquid assets with short-term liquid liabilities, namely, loans - the bank's main source of revenue - with cash deposits. Therefore, banks face a tradeoff between the risks resulting from lending too much and the forfeit revenue from keeping high reserves. In the liability side of bank b's balance sheet, we can find:

1. Capital, $K_{b}$. This is the bank's equity, and have no costs. It is updated throughout the cycle and used to evaluate the ROE, as we will see further ahead;

the effects of the two basic principles of learning - the law of actual effects and the law of simulated effects. 
2. Deposits, $D_{b}$. These are liquid liabilities. Bank $b$ have an exogenous number of depositors, whose deposits add up to $D_{b}$. The interest rate paid by banks over deposits is $i_{d}$;

3. Interbank loans - when bank $b$ is the borrower-I $B_{b}$. Banks take these loans in $t=1$, when they face the liquidity shock; they mature in $t=2$, therefore, its maturity is of one period. The interest rate in the interbank market, cost of these loans, is $i_{i}$;

4. Central bank loans, $C B_{b}$. Like interbank loans, central bank loans are used in period $t=1$ to face liquidity shortage. They also have maturity of one period. Their cost is $i_{c b}$.

Except for the capital, which has no cost, all the liabilities' costs are exogenous and identical to the entire system. Table 1 summarizes the liability side of banks' balance sheets.

Table 1 - Banks' liabilities

\begin{tabular}{cccc}
\hline Symbol & Liability & Maturity & Cost \\
\hline \hline$K_{b}$ & Capital & - & - \\
\hline$D_{b}$ & Deposits & $t+2$ & $i_{d}$ \\
\hline$I B_{b}$ & Interbank loans & $t+1$ & $i_{i}$ \\
\hline$C B_{b}$ & Central bank loans & $t+1$ & $i_{c b}$ \\
\hline
\end{tabular}

The assets of bank $b$ are:

1. Liquid assets, $L_{b}$. These are cash or cash equivalents and constitute the bank's reserves. They are used to face the depositors' withdraw requests and produce no return;

2. Interbank loans - when bank $b$ is the lender - $I L_{b}$. These are the same loans discussed in the liability side of the balance sheet, therefore work the same way, except that here bank $b$ will have return of $i_{i}$ instead of a cost;

3. Real sector loans, $R_{b}$. These are long-term (two periods) loans to real sector firms. These loans are made on $t=0$ and mature on $t=2$. Bank $b$ lends to the set $F_{b}$ of firms - which are represented individually — and the aggregate amount $R_{b}$ corresponds to the sum of those firms' loans. Therefore, the return of this asset depends on how each loan will perform ${ }^{5}$. The expected return of bank $b$ 's real sector loans is $E\left(r_{b}\right)$.

Table 2 summarizes the assets of banks.

$5 \quad$ Firm's behavior and the determinants of real sector loan's returns will be addressed ahead. 
Table 2 - Banks' assets

\begin{tabular}{cccc}
\hline Symbol & Asset & Maturity & Return \\
\hline \hline$L_{b}$ & Liquid assets & $t$ & - \\
\hline$I L_{b}$ & Interbank loans & $t+1$ & $i_{i}$ \\
\hline$R_{b}$ & Real sector loans & $t+2$ & $r_{b}$ \\
\hline
\end{tabular}

In order for banks to have incentives to lend to the real sector funded by deposits, there must be a positive spread between their $\operatorname{rates}^{6}$, i.e., $E\left(r_{b}\right)-i_{d}>0$. Furthermore, we do not want banks to fund real sector loans with central bank loans. Thus, we must observe the condition $E\left(r_{b}\right)-i_{c b}<0$, when setting the exogenous rates. Finally, the interbank interest rate should lay between deposits' cost $i_{d}$ and expected return from real sector loans $E\left(r_{b}\right)$. Summarizing this in one rule, we have:

$$
i_{c b}>E\left(r_{b}\right)>i_{i}>i_{d}
$$

\subsubsection{Bank strategy}

During simulations, banks play an iterated simultaneous game, in which they try to maximize their ROE. In the stage game, the strategy of bank $b, s_{b}^{j}$, is represented by $\left(\alpha^{j}, \beta^{j}\right)$, where $\alpha^{j}$ represents the ratio of capital to total liability and $\beta^{j}$ represents the ratio of liquid assets to total assets. The size of bank $b$ is exogenously set and represented by $T_{b}$. It corresponds to the sum of all assets or, likewise, the sum of all liabilities.

Thus, as in the beginning of each cycle $(t=0)$ there is no interbank activity - it will only take place in $t=1$ - the entire balance sheet is determined by the choice of strategy $s_{b}^{j}$ and by the exogenous size parameter $T_{b}$, as follows:

1. Capital:

$$
K_{b}=\alpha^{j} \cdot T_{b}
$$

2. Deposits:

$$
D_{b}=\left(1-\alpha^{j}\right) \cdot T_{b}
$$

3. Liquid assets:

$$
L_{b}=\beta^{j} \cdot T_{b}
$$

4. Real sector loans:

$$
R_{b}=\left(1-\beta^{j}\right) \cdot T_{b}
$$

$6 \quad$ As there is no fixed return to real sector loans - instead there is a distribution of returns-we must consider its expected value. Nevertheless, the condition mentioned in the text must still hold. 
By the end of a cycle, bank $b$ will calculate its profit (loss) as:

$$
\Pi_{b}=K_{b}^{2}-K_{b}^{0}
$$

where the superscripts in $K_{b}^{0}$ and $K_{b}^{2}$ are the periods $t$ in which the capital was measured. Afterwards, $R O E_{b}$, the variable taken in account by the learning scheme, is calculated as:

$$
R O E_{b}=\frac{\Pi_{b}}{K_{b}^{0}} .
$$

As we are concerned with policy implications in our analysis, it is interesting to define one more ratio here, which will be used further ahead: the capital adequacy ratio (CAR).

A bank's CAR is the ratio of capital to risk-weighted assets (RWA). In this framework, liquid assets are not included in the RWA - there are no relevant risks involving those assets - while real sector loans and interbank loans are. Thus, for bank $b$, we have:

$$
C A R_{b}=\frac{K_{b}}{I L_{b}+\sum_{f \in F_{b}} R_{b, f} \cdot w_{f}} .
$$

Eq. (2.11) was written this way to emphasize that firms can have different risk weights. This will be discussed ahead, when we get to the description of firms. For now, we must keep in mind that $R_{b, f}$ is the loan amount to firm $f$ and $w_{f}$ is its risk weight. One should also recall from the previous section that $K_{b}$ and $I L_{b}$ are capital and interbank loans, respectively, and $F_{b}$ is the set of firms borrowing from bank $b$.

If needed, a bank can adjust its CAR by selling part of its loan portfolio before it matures. In that case, it will incur a discount of $\delta_{L}$ to reflect the loss due to the asset's low liquidity.

\subsection{Central bank}

In our experiments, we are concerned with the central bank's purpose to maintain the financial system stability, namely, by acting as lender of last resort or financial system supervisor. Its role concerning monetary policy issues are set aside, as it does not offer much insight to our analysis.

When the central bank acts as lender of last resort, it helps banks with liquidity shortage. This happens when a bank does not hold enough liquid assets to face withdraws and cannot get enough liquidity from the interbank market. In this case, it can turn to the central bank to get the amount of liquidity necessary to honor the depositors' requests.

The role of system supervisor is performed through the establishment of capital requirements. In this case, the central bank sets the minimum capital adequacy ratio 
$\left(C A R_{\text {min }}\right)$ a bank must have in order to continue operating, i.e., all banks $b$ must meet the constraint $C A R_{b} \geq C A R_{\min }$. If a bank's capital adequacy ratio is below the minimum established, the central bank will force it to raise to the minimum. If it fails to do so, the central bank liquidates the bank.

\subsubsection{Central bank strategy}

In the cases that the central bank acts as the system supervisor, the capital requirement is set strategically through EWA learning. The strategy $s_{c b}^{j}$ is represented by $C A R_{\min }^{j}$ and the outcomes are system stability, measured by the number of bank insolvencies, and credit supply, measured by the total amount of real sector loans in the economy ${ }^{7}$.

In this framework, the central bank follows lexicographic preferences, choosing first strategies that lead to less insolvencies - more stability - then turning to the real sector loans. In other words, the central bank will always prefer the strategy that leads to the most stable system. Given two or more strategies with the same number of insolvencies - same level of stability - it will choose the one that leads to higher real sector loans.

\subsection{Depositors}

Following the Diamond and Dybvig (1983) framework, depositors' withdraw decisions will determine the liquidity shocks on banks. Depositors can be of two types:

1. Patient, who will wait until period $t=2$ for their deposits to mature, and withdraw the amount deposited plus the return; and

2. Impatient, who will withdraw in $t=1$ and give up the return, receiving only the amount deposited. For simplicity, we consider that an impatient depositor withdraws the total deposit amount in $t=1$.

Depending on the experiment, depositors can make their decisions strategically, according to the EWA learning scheme; or randomly, deciding with a certain probability if they will withdraw their resources early. In our simulations, there can be one or the other, according to what kind of analysis we are interested.

When depositors do not learn, the probability of depositor $d$ being impatient is $i m p_{d}$, set exogenously. This behavior is useful when we want to compare the resilience of the system facing liquidity shocks of different severities.

7 This approach is in line with (ELIZALDE; REPULLO, 2007), who defend that regulatory capital should be derived from a social welfare function that considers the cost of credit - in our case, the effects on credit supply - and the probability of bank failure. 


\subsubsection{Depositor strategy}

When depositors act strategically, they try to figure out whether their deposits are under jeopardy or not. Thus, the liquidity shocks will be the consequence of the level of risks assumed by banks, given that depositors wish to maximize their utility.

For a given depositor $d$, the risk tolerance parameter $\gamma_{d}$ is the only parameter used to define his strategy, $s_{d}$. It represents the minimum capital adequacy ratio he is willing to withstand in a bank, under which he decides to withdraw his deposits. This means that, in $t=1$, he compares $\gamma_{d}$ with his bank's capital adequacy ratio $C A R_{b}$. If $C A R_{b} \geq \gamma_{d}$ he accepts the risk incurred by bank $b$ and waits until $t=2$ to withdraw. On the other hand, if $\gamma_{d}>C A R_{b}$, depositor $d$ will not assume the risk of keeping his funds deposited in bank $b$ and withdraws in the short-term $(t=1)$. Depositors are always risk averse, with utility function given by:

$$
U_{d}\left(c_{d}^{1}, c_{d}^{2}\right)=\ln \left(\frac{c_{d}^{1}+c_{d}^{2}}{D_{d}}\right) .
$$

In the above equation, $c_{d}^{1}$ and $c_{d}^{2}$ represent consumption in short and long-term and $D_{d}$ represent the total amount deposited.

As all depositors have the same utility function and all of them are indifferent between consuming one unit in $t=1$ or in $t=2$, they will always be willing to give up the consumption of $D_{d}$ in the short-term, to consume $\left(1+i_{d}\right) D_{d}$ in the long-term, as long as the risks involved are acceptable. However, if they wait until $t=2$ and the bank that holds the deposits become insolvent, they lose their deposits and cannot have the expected consumption ${ }^{8}$. Summarizing, there are no inherently impatient depositors. What will determine if deposits will be withdrawn early is the risk assumed by banks.

\subsection{Firms}

In this framework, firms do not act strategically. However, they are represented individually, so we can capture the heterogeneity between them. This means that firms' loans will have different ratings, losses given default (LGD), risk weights and interest rates. Of course, the heterogeneities in each of these features are only present in simulations when they are relevant.

One must also note that, in this model, firms' demand for credit is inelastic. This means that they will borrow as long as banks supply credit. When banks' strategies lead to less real sector loans they are, in fact, leaving part of the demand untended. This is

8 In the case of an insolvency of banks, depositors can lose part or the total amount deposited. How bank insolvencies work will be discussed ahead. 
how we measure the impact over the real side of the economy in experiments. Firm $f$ have the following parameters defining it:

1. $R_{b, f}$, the loan amount firm $f$ took from bank $b$;

2. $i_{f}$, the interest rate payed by firm $f$;

3. $P D_{f}$, the probability of $f$ not honoring its commitments (probability of default);

4. $L G D_{f}$, the loss given default regarding firm $f$. This is the loss a bank will suffer in the event of a default in the loans to $f$; and

5. $w_{f}$, the risk weight of firm $f$. The risk weights are used to measure banks' capital adequacy ratios.

Once with these parameters, we can calculate the expected return of bank b's real sector loans, as $^{9}$ :

$$
E\left(r_{b}\right)=\frac{\sum_{f \in F_{b}} R_{b, f} \cdot E\left(r_{b, f}\right)}{R_{b}},
$$

where $E\left(r_{b, f}\right)$ is the expected return of firm f's loan and $F_{b}$ is the set of all firms with loans in bank $b$. The expected return of firm $f$ 's loan, $E\left(r_{b, f}\right)$, is:

$$
E\left(r_{b, f}\right)=E\left(\frac{R_{b, f}^{2}-R_{b, f}^{0}}{R_{b, f}^{0}}\right),
$$

where $R_{b, f}^{0}$ is the loan amount firm $f$ took from bank $b$ in $t=0$ and $R_{b, f}^{2}$ is this loan's amount in $t=2$, when it matures, which can be:

- $R_{b, f}^{0} \cdot\left(1+i_{f}\right)$, with probability $1-P D_{f}$; or

- $\left(1-L G D_{f}\right) \cdot R_{b, f}^{0} \cdot\left(1+i_{f}\right)$, with probability $P D_{f}$.

Hence, the expected value of firm $f$ 's loan in $t=2$ is:

$$
\begin{aligned}
E\left(R_{b, f}^{2}\right) & =R_{b, f}^{0} \cdot\left(1+i_{f}\right) \cdot\left(1-P D_{f}\right)+\left(1-L G D_{f}\right) \cdot R_{b, f}^{0} \cdot\left(1+i_{f}\right) \cdot P D_{f} \\
& =R_{b, f}^{0} \cdot\left(1+i_{f}\right) \cdot\left(1-P D_{f} \cdot L G D_{f}\right) .
\end{aligned}
$$

$\overline{9}$ Every expectation here is conditional to the information available in $t=0$, when banks set their strategies. For cleaner notation, we will omit the conditional expectations. 
Substituting Eq. (2.15) into Eq. (2.14), we have the expected return of firm's loans:

$$
E\left(r_{b, f}\right)=\left(1+i_{f}\right) \cdot\left(1-P D_{f} \cdot L G D_{f}\right)-1
$$

Therefore, from Eq. (2.16) into Eq. (2.13), the expected return of bank b's real sector loans is:

$$
E\left(r_{b}\right)=\frac{\sum_{f \in F_{b}} R_{b, f} \cdot\left[\left(1+i_{f}\right) \cdot\left(1-P D_{f} \cdot L G D_{f}\right)-1\right]}{R_{b}} .
$$

Eq. (2.17) will be used to verify that the condition in Eq. (2.4) is met by experiments' parameters.

\subsection{Interbank market structure}

In this section, we discuss some issues that arise from the interaction of banks in the interbank market, namely, information asymmetry and the existence of a clearinghouse with collateral requirements. After that, we also discuss the implications of bank insolvencies and how contagion occurs.

The features discussed here take part after banks face the liquidity shock and seek the interbank market, in $t=1$. They also affect the long-term, when banks liquidate their interbank positions.

\subsubsection{Information asymmetry}

In this framework, there are two possible setups regarding the information participants have about one another:

1. Perfect information, i.e., there is no asymmetry and each interbank participant have full knowledge about each other's balance sheets and risks;

2. Asymmetric information, when banks cannot perceive the risks assumed by their counterparties and, therefore, cannot define their interbank relations based on how safe other banks are.

Perfect information setups are important to assess the effects of market discipline in the interbank network. Under that assumption, banks will prefer to sign loans with other banks that play safer strategies, aiming to minimize the risk of an interbank default.

In order to incorporate this feature, we model the interbank market to function as follows: banks form two queues, representing supply and demand for liquid assets. To get 
interbank discipline, those queues are sorted by capital ratio $(\alpha)$ and then by liquidity ratio $(\beta)^{10}$. In other words, banks with higher capital ratios will have priority in the interbank market. When two banks have the same capital ratio, the one with higher liquidity ratio comes first. The practical effects of market discipline for banks are:

- When the entire interbank liquidity supply is exhausted, banks that could not cover their liquidity shortage have to resort to the central bank or sell illiquid assets at discounted prices to face withdraws. This makes it valuable to be in the early positions of the interbank queue, and makes market discipline an extra incentive for banks with liquidity shortage to choose safer strategies; and

- On the other hand, if all banks demanding liquid assets satisfy their needs before the market supply is fully lent, the remaining banks are left with idle liquid assets until the long-term, in $t=2$, having no returns over these assets. Besides, even when a risky bank gets to lend its liquidity excess, it lends to banks with riskier strategies as well, increasing the risk of a default. Consequently, even banks with excess liquidity will benefit from safer strategies under market discipline.

Despite the positive implications of perfect information to the financial system, asymmetric information makes a more realistic assumption. When this is the case, banks are unable to observe the strategies of other banks, and cannot determine whether they are risky or not. Thus, arises a problem of adverse selection.

In this case, the interbank setup gets a little simpler. Banks still form two queues, one for demand and one for supply of liquidity. The key difference from the previous case is that, as long as banks cannot discriminate between risky and non-risky counterparties, the participants are randomly sorted in both queues. This produces the desired effect of the behavior of banks under adverse selection.

\subsubsection{Clearinghouse}

The framework also allows us to study the introduction of a clearinghouse, responsible for clearing loans and for collecting collateral from market participants. Its purpose is to reduce systemic risk by assuring, at least partially, settlements in the interbank market.

In the setups with a clearinghouse, it operates as the central counterparty in the interbank market. Thus, when a bank needs liquid assets to face the liquidity shock in $t=1$, it signs a contract with the clearinghouse, and not directly with other banks. This is also true for banks with liquidity excess. However, as the clearinghouse doesn't have any assets of its own - it only directs the excess liquidity to banks with liquidity

$\overline{10}$ Recall, from the description of banks' strategies, that these are the parameters that define a strategy $s_{b}^{j}$ 
shortage - there can still be disequilibrium between supply and demand. In this case, the priority determining which banks will fulfill their transactions follows the rules discussed in the previous section.

As mentioned, the clearinghouse also requires collateral from participants with debt positions, which have to commit resources to a mutual fund ${ }^{11}$. To determine the total amount this fund must have, we follow the recommendations from (BIS, 2001), which states that it must be large enough to ensure the completion of settlements in case of the default by the participant with the largest debt position. Finally, every bank borrowing liquidity in the interbank market has to provide collateral proportional to the size of its interbank loans. The following equations summarize these rules:

$$
g_{b}=\frac{l s_{b}}{\sum_{i \in B^{S}} l s_{i}} \cdot \max \left(l s_{i}\right),
$$

where $g_{b}$ and $l s_{b}$ are the collateral amount and the liquidity shortage of bank $b$ and $B^{S}$ is the set of all banks with liquidity shortage. This way, the mutual fund's size, $G$, will be:

$$
G=\sum_{i \in B^{S}} g_{i}=\max \left(l s_{i}\right)
$$

\subsubsection{Insolvencies and contagion}

Banks become insolvent when their losses exceed their capital. An insolvent bank goes into a special liquidation regime, and the central bank gets responsible for selling its assets and repaying its liabilities. In those cases, its real sector loans suffer a penalty of $\delta_{I}$ in their value, which represents the losses due to the depreciation of those assets in the market and the extra costs resulting from the liquidation process ${ }^{12}$. Therefore, when a bank becomes insolvent, its losses are far greater than when its capital is enough to absorb them. This feature brings into the model the relevance insolvencies have in the real world, and adds an extra incentive for banks to avoid it.

When the central bank repays the liabilities of insolvent banks, it prioritizes central bank loans. Afterwards, the interbank loans are repaid and, finally, the remaining resources are destined to depositors. If the insolvent bank's resources run out before the interbank loans are repaid, the unpaid interbank loans are defaulted. Therefore, contagion take place through the channel of direct interbank exposure.

Interbank defaults can, depending on how connected banks are, spread losses across the system. To measure how prone a setup is to contagion, we use the number of

\footnotetext{
11 Note that the collateral resources in the mutual fund must be available when the interbank loans mature, i.e., in $t=2$. Thus, real sector loans can be used as collateral.

12 The rationale behind this argument is based on Diamond and Rajan (2001).
} 
insolvencies induced by interbank exposure.

\subsection{Events within cycles}

As previously mentioned, a cycle is divided into three periods: today, with $t=0$; short-term, with $t=1$; and long-term, with $t=2$. Below, we deepen the discussion about the sequence of events within cycles, describing the agents' decisions and actions in each of these time horizons ${ }^{13}$ :

1. Today, $t=0$. This is when agents make their decisions and the whole model is set to the new cycle:

a) This period begins with agents choosing their strategies, i.e., banks set their values for $(\alpha, \beta)$, depositors set their values for $\gamma$ and the central bank sets the value for $C A R_{\min }$. To do that, they consider the experience acquired through the EWA learning model in previous cycles;

b) Afterwards, the economy's parameters are set. Here, banks' chosen strategies are used to calculate their amounts of capital, deposits, liquid assets, and real sector loans, according to Eqs. (2.5) to (2.8).

2. Short-term, $t=1$. In this period banks face the liquidity shock. Hence, the interbank transactions emerge as a response to that.

a) As mentioned, at the beginning of this time horizon banks face a liquidity shock, represented by the withdraws of impatient depositors (or depositors who perceive the risks of keeping their deposits as too high).

b) First, banks face these withdraws with their reserves;

c) Afterwards, banks with insufficient liquidity borrow liquid assets from banks with excess liquidity in the interbank market (directly or through the clearinghouse, depending on the setup);

d) Finally, if even after interbank transactions some bank still do not have enough liquid assets to face withdraws, it resorts to the central bank, who acts as the emergency lender. The central bank provides the liquidity needed to honor the remaining withdraws;

e) The central bank then performs its role as the system supervisor, acting upon banks whose risks - measured by the capital adequacy ratio - are too high. The supervisor forces those banks to sell illiquid assets at discounted prices in order to raise the CAR to meet the requirements.

13 The discussion here targets a comprehensive version of the model. Some of the events described now may not be present in particular experiments. These particular cases will be addressed in the next section, when we analyze the model's results. 
3. Long-term, $t=2$. In the long-term, banks realize their profits; deposits, interbank and real sector loans mature, and every agent updates its attraction function.

a) The long-term begins with banks updating their balance sheets, by updating their liabilities' values according to their costs and their assets' values according to their returns;

b) Banks whose losses exceed their capital become insolvent. The central bank liquidates those banks, applying a penalty over their assets' values. This further increases the loss for those banks, raising incentives, in terms of payoffs, to avoid this situation in future cycles;

c) Insolvent banks' assets are used to repay their liabilities, as long as possible and according to the priority discussed in the previous section, namely, central bank loans, interbank loans and deposits, in this order;

d) Defaulted interbank loans can cause local losses to spread across the system. In turn, the new losses can cause other banks to become insolvent. Through this channel, financial contagion can cause local events to assume systemic proportions;

e) Closing the cycle, every agent updates the payoff of the actually chosen strategy and simulate the payoffs of other strategies, in order to update the attraction function in the EWA learning model. An agent calculates its simulated payoffs varying only its own strategy, keeping fixed the strategies of every other agent in the economy.

When a cycle ends, the next one begins, and agents carry only the experience acquired throughout cycles. All other variables are restored to their default values. 


\section{Policy experiments}

Our experiments will assess the impacts of different regulation policies over the banking system ${ }^{1}$. In order to do that, we run simulations with policy representations and compare them to their counterfactuals, i.e., simulations with the same scenario without the adoption of the policy.

Simulations consist of Monte Carlo experiments, with a large enough number of cycles repeated 100 times, so we have a distribution of results for each cycle. The mean and its $95 \%$ confidence interval for those distributions are plotted so we can assess how the variables of interest evolve in time. Besides, before plotted, every result is smoothed by the LOWESS method ${ }^{2}$. The number of cycles varies according to how many it takes for variables to reach a stable level ${ }^{3}$.

As we are interested in the impacts of different policy frameworks over the system, we need to define how we will measure each effect. The outputs of our model and their corresponding measures are:

- Insolvencies. We use the total number insolvent banks, independent of what led to insolvency;

- Contagion. Here, we use insolvencies caused by defaults in interbank exposures. Note that this is a subset of the insolvencies measure;

- Impact over the real side of the economy. As mentioned when discussing firms parameters, we use the amount of real sector loans to assess how the banking system affects the real side of the economy. As firms' demand for credit is inelastic, less loans mean untended demand, leading to production projects not carried out by firms;

- Overall interbank dependencies. This is measured by the amount of interbank loans;

1 Our objective here is to run a handful of experiments to explore relevant policy setups. We do not mean to explore the whole power of the model, which goes way beyond the scope of this work.

2 LOWESS, or LOESS, a locally weighted regression method, which combines multiple regression models to smooth scatterplots (CLEVELAND, 1981).

3 The time it takes to perform a simulation depends on the number of cycles, on the number of repetitions and on what and how many agents are acting strategically (through EWA learning). Our default simulation setup, with 10 banks learning, 100 repetitions and 2000 cycles, took around 3 hours. However, when we allowed depositors to act strategically as well, with 100 depositors per bank, and thus adding 1000 learning depositors, the simulation took around 20 hours. For a discussion on the computational aspects of the model, see Lima (2014). 
- Bank runs. Measured by the number of banks which faced a large number of withdraw requests in the short-term $(t=1)$. Captures the severity of the liquidity shock over the system;

- Capital allocation. We use aggregated bank capital or average CAR. This measure captures the capital buffer banks keep to face risks; and

- Banking sector profitability. Measured by the average ROE, it captures the average return of one unit of capital in the banking sector.

Some other variables, such as liquidity ratio and aggregate liquid assets, can also sometimes be used to analyze bank's strategic decisions.

Recall that a cycle consists of the three time periods covered in the previous section, with $t=0,1,2$. Decision variables, such as the amount of loans banks supply to the real sector or the amount of capital they decide to hold, are measured at the beginning of the cycle (in $t=0$ ). Result variables - variables that reflect interactions and outcomes, such as insolvencies, contagion or interbank loans - are measured at the end of cycles, in $t=2$.

We must also define the EWA learning parameters, which will be the same for every simulation. The depreciation of experience, with $\rho=0$, and the depreciation of attractions, with $\phi=1$, associated with initial experience $N(0)=1$, make strategies' attractions independent of the amount of experience. In other words, strategies attractions will not be influenced by the number of past periods, just by what agents learned in them.

The weight of foregone strategies $\delta=1$ results in equal importance for strategies chosen and strategies simulated, i.e., the law of actual effects and the law of simulated effects are equally important to agents. In the beginning of the learning process, the probability of choosing a certain strategy is the same as the probability of choosing any other, thus initial attractions are $A^{j}(0)=0$, for all strategies $j$. Finally, the parameter that captures the sensitivity of agents to attractions in the logit model is $\lambda=1$. Table 3 summarizes these parameters' values.

Table 3 - Learning parameters

\begin{tabular}{ccc}
\hline Symbol & Parameter & Value \\
\hline \hline$\rho$ & Experience depreciation & 0 \\
\hline$\phi$ & Past attractions depreciation & 1 \\
\hline$N(0)$ & Initial experience & 1 \\
\hline$\delta$ & Foregone payoffs' weight & 1 \\
\hline$A(0)$ & Initial attractions & 0 \\
\hline$\lambda$ & Sensitivity to attractions (logit model) & 1 \\
\hline
\end{tabular}


As happens in the learning scheme, some of our model's parameters will be fixed in all of our experiments. Others seldom vary, making it interesting to define a basic structure to our simulations. Therefore, the basic structure consists of a setup with an interbank market and with the central bank acting as lender of last resort, providing liquidity to banks that could not find it in the interbank market. Besides, there is no interbank clearinghouse and banks do not have information about each other's balance sheets, thus, they cannot observe their counterparties' risks - there is information asymmetry, as described earlier. Finally, all banks have the same size, depositors do not consider banks' risks in their withdraw decisions - which are determined by an exogenous probability - and firms are assumed to operate in the same segment, with the same value for the parameters that define them. Table 4 describe the basic economy's parameters.

Table 4 - Benchmark parameters

\begin{tabular}{ccc}
\hline Symbol & Parameter & Value \\
\hline \hline- & Number of repetitions (Monte Carlo) & 100 \\
\hline- & Depositors per bank & 100 \\
\hline$B$ & Number of banks & 10 \\
\hline$T_{b}$ & Banks' size (total assets or total liabilities) & 1 \\
\hline$i_{d}$ & Deposits' return & $0.5 \%$ \\
\hline$i m p_{d}$ & Probability of impatient depositor & $15 \%$ \\
\hline$F_{b}$ & Number of firms per bank & 50 \\
\hline$i_{i}$ & Interbank interest rate & $1 \%$ \\
\hline$i_{c b}$ & Central bank's loans interest rate & $2.5 \%$ \\
\hline$\delta_{L}$ & Depreciation of illiquid assets sold before maturity & $25 \%$ \\
\hline$\delta_{I}$ & Depreciation of insolvent banks' real sector loans & $40 \%$ \\
\hline
\end{tabular}

We now proceed to experiments. Over the next sections, we will discuss the creation of an interbank clearinghouse, the adoption of the Basel Accord's regulatory guidelines and the implementation of a deposit insurance. However, we begin by discussing the economic scenarios used as baseline in our studies and, more specifically, the effects of the interest margin in the banking system.

\subsection{Bank interest spread}

It is not new to the economic literature that the level of development of the banking system exerts direct impact over economic growth (LEVINE, 1997; DEMIRGUC-KUNT; HUIZINGA, 1999; BECK; LEVINE; LOAYZA, 2000). As an indicator of banking systems' efficiency, Demirguc-Kunt and Huizinga (1999) propose the bank interest spread - the difference between banks' cost of funding and their return from loans. 
Since the seminal work of Ho and Saunders (1981), research has provided many causes to the diverging interest spreads observed across banking systems. Those causes range from macroeconomic factors - such as inflation, monetary policy and economic cycles - to microeconomic factors - such as market concentration, transaction costs and information asymmetries ${ }^{4}$. Moreover, evidence shows that wider interests spreads are more common among developing countries (DIETRICH; WANZENRIED; COLE, 2015; BROCK; SUAREZ, 2000).

The impact of different interest spreads over the banking system is the first issue we will explore in our experiments. Given that in our model all interest rates are exogenous, we can explore this issue ceteris paribus, setting parameters properly. In order to achieve that, we follow the Demirguc-Kunt and Huizinga (1999) definition of ex ante spread as the difference between the contractual rates charged on loans, $i_{f}$, and the rates paid on deposits, $i_{d}$. Thus, we alter only the interest rate of firms' loans ${ }^{5}, i_{f}$, keeping in mind the restriction in Eq. (2.4). Table 5 show the parameters for this experiment.

Table 5 - Bank interest spread experiment parameters

\begin{tabular}{ccc}
\hline Symbol & Parameter & Value \\
\hline \hline$P D_{f}$ & Probability of default & $4.5 \%$ \\
\hline$L G D_{f}$ & Loss given default & $1 \%$ \\
\hline$w_{f}$ & Risk weight & $100 \%$ \\
\hline$i_{f}^{h}$ & High spread scenario interest rate & $8 \%$ \\
\hline$i_{f}^{l}$ & Low spread scenario interest rate & $6 \%$ \\
\hline
\end{tabular}

Figure 1 compares the outcomes of the different spread scenarios. Panel (a) shows that, with wider spreads, the system gets more unstable, with greater number of insolvencies per simulation cycle. The width of the confidence intervals also imply greater the volatility in this scenario.

Panel (b) did not show significant difference for contagion at 95\% confidence level. However, the two scenarios show different behavior, with the narrower interest spread leading to the complete absence of contagion after about three hundred simulation cycles. These results suggests that the wider interest spread gets, the less stability is observed in the banking system.

Contagion is highly determined not only by the number of insolvencies, but also by how interconnected banks are. Panel (c) shows that, with high interest spreads, banks choose

4 See Demirguc-Kunt and Huizinga (1999) for a comprehensive discussion on bank interest spread determinants.

5 The findings of Brock and Suarez (2000) also guided this choice of simulation setup. Their results suggest that the interest spread is more correlated with loan rates than with deposit rates. 
strategies that lead to greater interbank exposure, making the system more vulnerable to contagion.

Looking at panel (d), we understand the key difference in banks' strategies that makes the high interest spread scenario more unstable: their capital allocation choice. In order to maximize their ROE, banks choose strategies with lower levels of capital allocation. This strategy reduces the capital buffer banks hold to face losses. As a result, even small losses can trigger insolvency events, which become more frequent.

Finally, panel (e) depicts an intuitive result: higher interest margins lead to higher return on equity in the banking sector. In fact, the ROE of banks facing wider interest spread were about four times their ROE when the interest spread was narrower. Moreover, the width of the confidence intervals in panel (e) shows that returns are more volatile with higher spreads. This is another consequence of the greater instability depicted in panel $(\mathrm{a})^{6}$.

In their study of the determinants of bank interest margins across countries, Dietrich, Wanzenried and Cole (2015) found that lower interest margins are associated with more developed financial systems. Brock and Suarez (2000) had similar results in their study of Latin American countries. Our results follow the same direction, suggesting that lower bank interest spread is associated with greater systemic stability.

Despite not being a study of the direct impact of regulatory policies on the interest spread $^{7}$, which is exogenous to our model, this experiment provided examples of how the stability of financial systems can vary across countries, what can, in turn, lead to different results from policy implementation. Therefore, the scenarios in this section will serve as counterfactual to the adoption of regulatory policies over financial systems with different levels of stability.

\subsection{Interbank clearinghouse}

Clearinghouses are institutions that operate as central counterparties in many financial markets, especially those operating derivatives ${ }^{8}$. They are designed to insure counterparty risk by replacing the original contract between buyer and seller by two new contracts, one between the buyer and the central counterparty and another between the central counterparty and the seller (KOEPPL; MONNET, 2010). However, this alone is not enough to eliminate the risk from default. Hence, clearinghouses usually require collateral - or margins - from participants (EVANOFF; STEIGERWALD; RUSSO, 2006).

6 One must recall the effects of insolvencies over banks' returns discussed in Section 2.6.3.

7 For an assessment of regulatory policies over interest margins see Demirguc-Kunt, Laeven and Levine (2003).

8 For surveys on clearinghouses and central counterparties see Knott and Mills (2002), Koeppl, Monnet and Temzelides (2012), Koeppl and Monnet (2010). 
Figure 1 - Bank interest spread experiment results

(a)

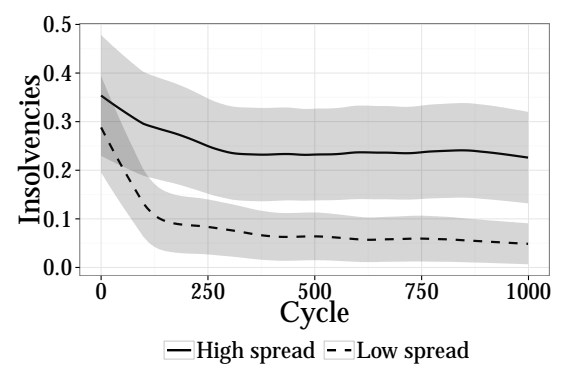

(c)

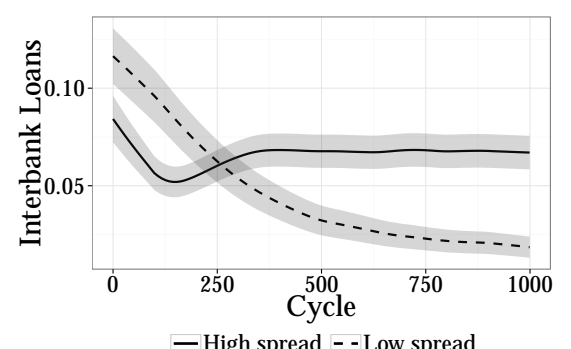

(b)

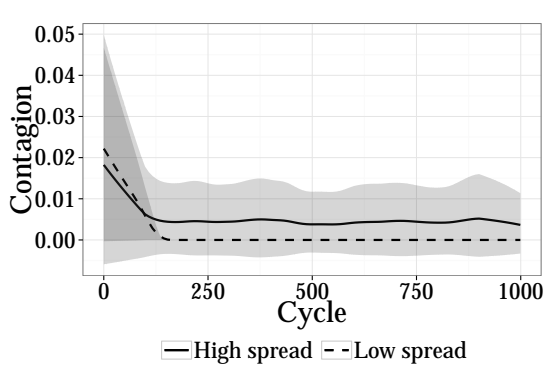

(d)

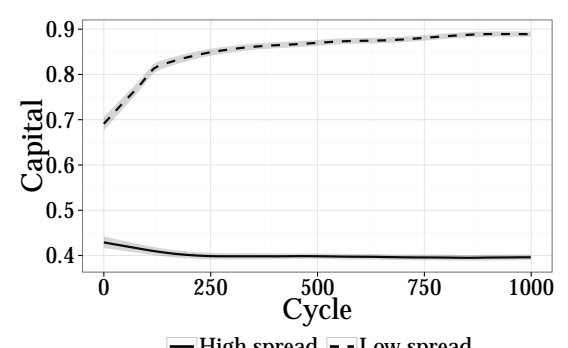

(e)

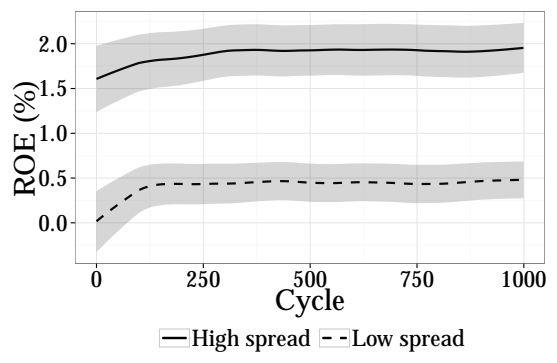

As described in Section 2.6.2, the clearinghouse structure adopted in our model is a rather simple implementation, with the clearinghouse acting only as central counterparty in the interbank system and requiring collateral from banks. Other more sophisticated structures could involve clearinghouses deriving margin requirements from a maximization problem or even acting as lender of last resort (JAREMSKI, 2015).

Empirical evidence suggests that the clearinghouse effects may differ according to the economic environment (JAREMSKI, 2015). We, therefore, run this section's simulations using the two scenarios discussed in the previous experiment as counterfactual. Thus, the baseline parameters are identical those in Table 5 and the clearinghouse operates as described in Section 2.6.2, acting as the central counterparty in the interbank market and requiring collateral from member banks. Besides, it also requires information disclosure of participants, in order to monitor their risks, eliminating information asymmetry as described in Section 2.6.1.

Figure 2 shows the outcomes of the adoption of a clearinghouse in the more unstable 
scenario discussed in the previous section - characterized by high interest spreads. In panel (a), we can see how contagion was affected. This result suggests that the clearinghouse is successful in reducing the risk of contagion in the system. In fact, over the 100 repetitions of the 1500 simulation cycles with the clearinghouse, there was not even a single case of bank insolvency caused by contagion.

The reduction in systemic risk is not caused by the reduction of interbank exposure, as we can see from panel (b). Despite not significant at $95 \%$ confidence interval, this outcome suggests that if there were to be any shifts in the level of interbank loans, it would be upwards. Empirical evidence supports this result (JAREMSKI, 2015).

However, the gains in terms of stability comes at a cost in terms of real sector loans. Panel (c) shows a slight, yet significant, reduction in credit supply. Furthermore, although effective in the reduction of contagion, the clearinghouse does not affect the number of insolvencies discounting those caused by interbank exposure, as depicted in panel (d).

Figure 2 - Clearinghouse experiment results

(a)

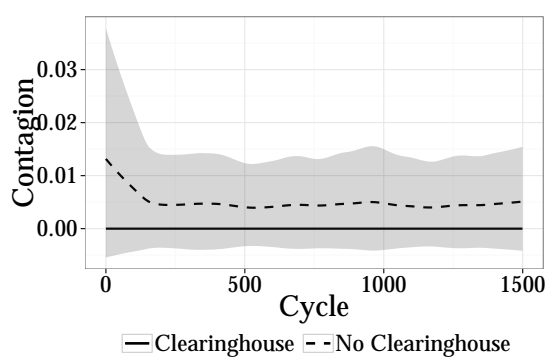

(c)

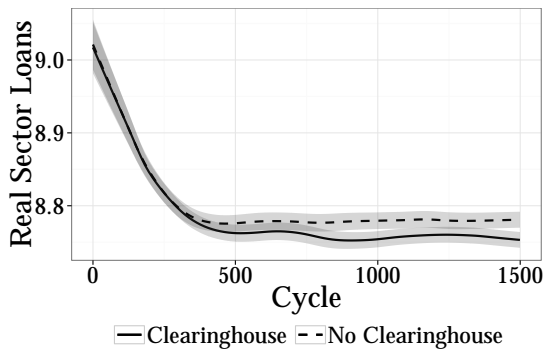

(b)

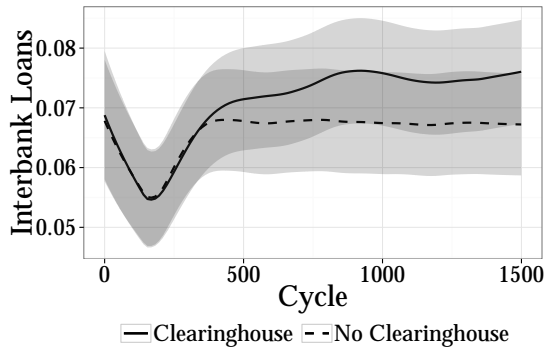

(d)

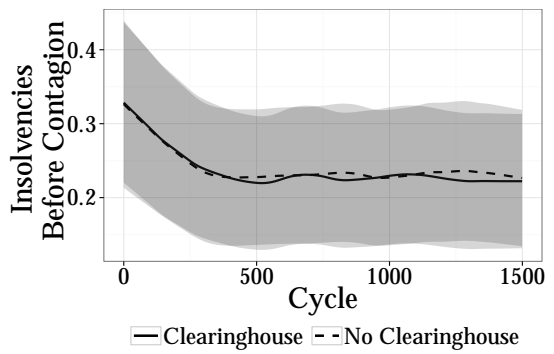

Our simulation considering the more stable scenario - the one with narrower interest margins - does not present significant changes in the presence of the clearinghouse ${ }^{9}$. This happens due to the low number of insolvencies caused by contagion in the baseline simulation. As our clearinghouse setups aims the reduction of contagion, this result is rather straightforward. However, it is important to observe that the costs described in the unstable scenario experiment are not observed in the stable one, suggesting that the

$9 \quad$ For a clearer presentation of results, we will omit the figures for this scenario, once all of the model's outcomes remained at the same levels as those of the baseline. 
clearinghouse costs in terms of credit supply are only observed in times that the risk of contagion is present. When this risk becomes insignificant, also does the reduction of real sector loans.

\subsection{Basel Accord policy framework}

Nowadays, capital regulation is not an exception in banking sector policies around the world (BARTH; CAPRIO; LEVINE, 2013). Since its first version, in 1988, the Basel Accord's primary goal was to promote the stability of banking systems in response to increasing risk, by establishing minimum requirements on banks' capital levels. In 2004, the accord's revised framework, known as Basel II, introduced the concept of the three pillars of baking regulation: (i) capital requirements; (ii) supervisory review; and (iii) market discipline. The experiment discussed in this section is based on this regulatory framework $^{10}$.

In order for our model to capture the effects of Basel's three pillars, we use the combination of some of the features discussed in Section 2, as follows:

1. Pillar One: Capital Requirements. This pillar is explicitly present in the setup, with the capital requirement mechanism functioning as described in Section 2.3.

2. Pillar Two: Supervisory Review. This pillar is captured by the adaptive behavior of the central bank, who sets the capital requirements in order to reduce the systemic risk.

3. Pillar Three: Market Discipline. This pillar is present in the ability of banks to observe each other's risk parameters, as described in Section 2.6.1. This is achieved by the imposition banks' information disclosure by the system supervisor; hence, it is part of the policy setup.

Furthermore, a particularity involving this experiment is that banks now have two loan portfolios: retail and corporate. For simplicity, we consider that each portfolio corresponds to firms of different segments of the economy. Hence, we can think of banks' loans heterogeneity in terms of firms' heterogeneity, which will have different values for their parameters. Finally, the risk weights used for the two kinds of firms follow the Standardized Approach to Measure Credit Risk (BIS, 2006), for retail and corporate loans. Table 6 shows this simulation's parameters.

Figure 3 show this experiment's results. As we can see in panel (a), the guidelines of the Basel Accord are successful in reducing the number of bank insolvencies, thus leading

$\overline{10}$ For the comprehensive version of the revised framework, see (BIS, 2006). 
Table 6 - Basel Accord experiment parameters

\begin{tabular}{ccc}
\hline Symbol & Parameter & Value \\
\hline \hline$i_{f}^{r}$ & Interest rate of retail portfolio's loans & $8 \%$ \\
\hline$P D_{f}^{r}$ & Probability of default of retail portfolio's loans & $6 \%$ \\
\hline$L G D_{f}^{r}$ & Loss given default of retail portfolio's loans & $75 \%$ \\
\hline$w_{f}^{r}$ & Risk weight of retail portfolio's loans & $75 \%$ \\
\hline$i_{f}^{c}$ & Interest rate of corporate portfolio's loans & $6 \%$ \\
\hline$P D_{f}^{c}$ & Probability of default of corporate portfolio's loans & $4 \%$ \\
\hline$L G D_{f}^{c}$ & Loss given default of corporate portfolio's loans & $100 \%$ \\
\hline$w_{f}^{c}$ & Risk weight of corporate portfolio's loans & $100 \%$ \\
\hline
\end{tabular}

to greater stability. Panel (b) shows that this happens due to the improved capital buffer banks hold to absorb losses, as intended by the Basel Accord.

As mentioned earlier, the capital requirements are implemented as a restriction upon banks' CAR. Panel (c) shows how the requirement shifts banks' adaptive strategies. There are two noteworthy effects here:

First, capital requirements are binding, i.e., the minimum level of CAR defined by the central bank is higher than the level banks would choose if unconstrained. This is an interesting result in terms of the discussion involving regulatory and economic capital. As Elizalde and Repullo (2007) define, regulatory capital is the minimum level imposed by the regulator, derived from a social welfare function, as mentioned in Section 2.3.1, and economic capital is the level of capital banks choose in the absence of regulation to face losses. Our results suggest that banks' economic capital are below the social optimal, what supports the rationale for capital regulation behind the Basel Accord ${ }^{11}$.

Second, the actual capital level banks choose when restricted by regulation is significantly above the requirement. This happens due to the policy response to undercapitalized banks. As our model considers that banks that do not meet the capital requirements are forcefully closed by the central bank, they choose higher amounts of capital to avoid that losses reduce their CAR to levels below the regulatory minimum. This result is in line with those of Elizalde and Repullo (2007), who stress that such rigorous policy result in higher capital allocation.

Finally, panel (d) shows that, in addition to the increase in capital levels, banks also reduce the supply of real sector loans to meet the restrictions upon their CAR. This result suggests that Basel's regulatory framework can, in fact, result in a credit crunch in the economy, i.e., a significant reduction of the credit supplied by banks, as suggested

$11 \quad$ For further discussion on regulatory and economic capital see Repullo and Suarez (2004) and Elizalde and Repullo (2007). 
by the economic theory (COSIMANO; CHAMI; BARAJAS, 2004; NACEUR; KANDIL, 2007).

Figure 3 - Basel Accord experiment results

(a)

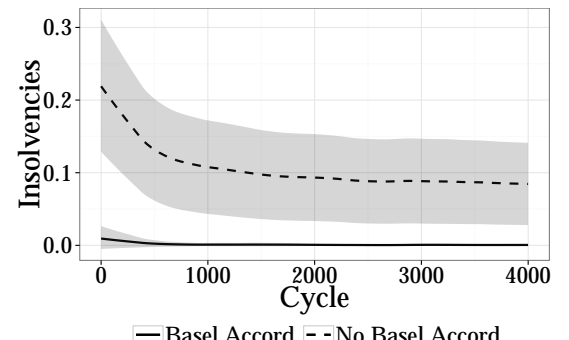

(c)

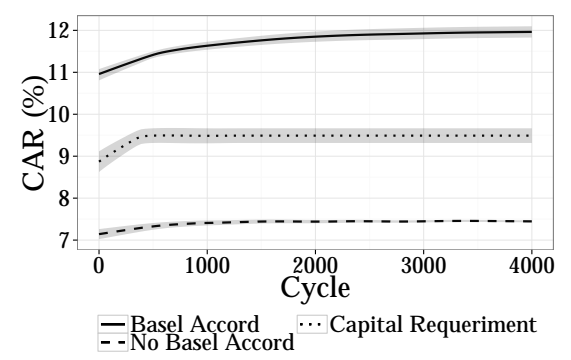

(b)

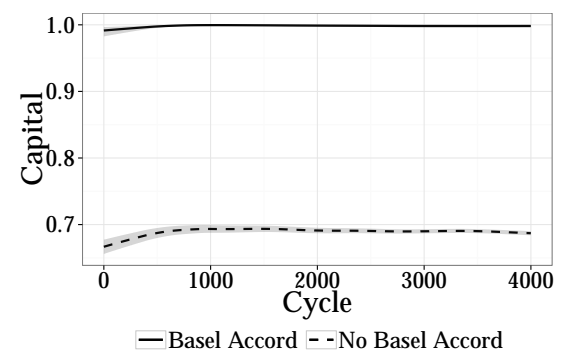

(d)

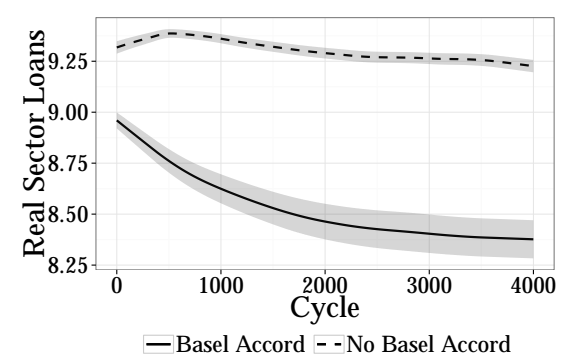

\subsection{Deposit insurance}

In order to improve the stability of banking systems during the global financial crisis, a large number of countries strengthened their deposit insurance schemes. This arouse the interest of economic theory on the effects of this instrument on the banking sector. The literature stresses that, on the one hand, deposit insurances can, in fact, reduce depositors' incentives to engage in bank runs. On the other hand, it also reduces their incentives to monitor banks' risks, thus reducing benefits from market discipline ${ }^{12}$ (ANGINER; DEMIRGUC-KUNT; ZHU, 2014).

Deposit insurances are an instrument to protect household deposits from banking crisis, covering depositors' losses in case of bank insolvency ${ }^{13}$. The deposit insurance scheme adopted in our model provides full coverage to the losses depositors may incur due to bank insolvency, thus, acting as a safety net to household deposits. Therefore, it creates incentives for depositors to avoid early withdraws, reducing the risk of bank runs. If a large number of depositors decide to withdraw at the same time, illiquid banks

12 In Section 3.3, we discussed the implications of market discipline in the interbank network. In this section, we incorporate another form of market discipline, imposed by depositors. For a discussion on depositor discipline, see Bennett, Hwa and Kwast (2015).

13 For a survey on deposit insurance schemes, see Demirguc-Kunt, Kane and Laeven (2015). 
could rapidly become insolvent (BARTH; CAPRIO; LEVINE, 2004). However, it also reduces incentives for depositors to monitor banks, encouraging excess risk-taking behavior. Empirical evidence shows that the latter effect may offset the stabilization benefits from the former (DEMIRGUC-KUNT; DETRAGIACHE, 2002; BARTH; CAPRIO; LEVINE, 2004).

To simulate the adoption of a deposit insurance during a period of financial crisis, we use as baseline scenario a setup similar to that used as high spread scenario in Section 3.1, which led to greater instability. However, in this experiment depositors make strategic decision as discussed in Section 2.4, thereby restraining banks' risk-taking behavior and incorporating market discipline. We then compare this baseline scenario to the same setup with deposit insurance available.

Figure 4 - Deposit insurance experiment results

(a)

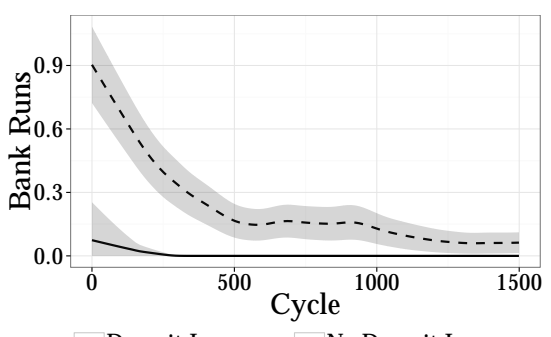

(c)

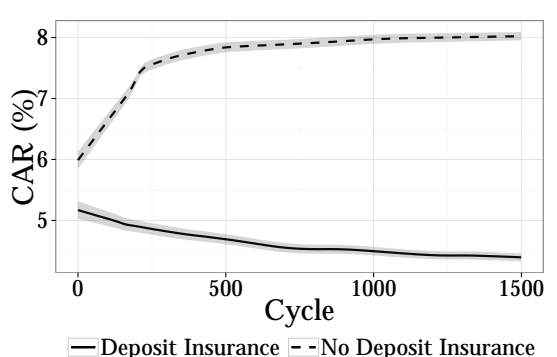

(b)

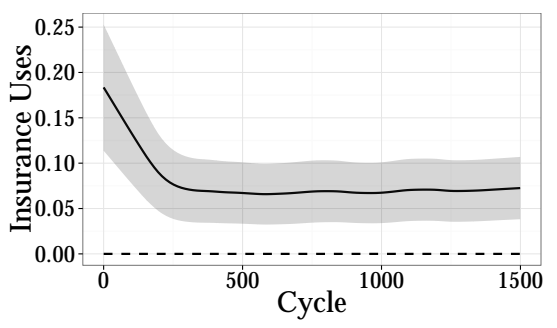

-Deposit Insurance - - No Deposit Insurance

(d)

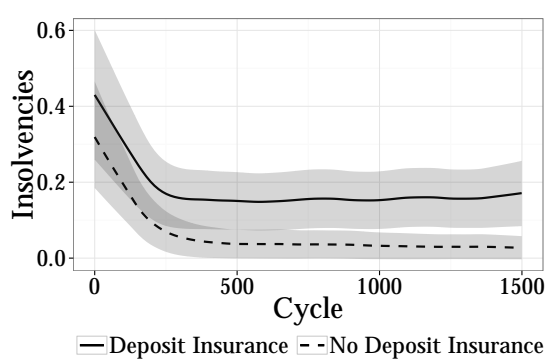

Figure 4 shows the results for this experiment. As we can see in panel (a), the adoption of the deposit insurance successfully reduces the number of bank runs in the economy, with this risk being completely mitigated a few cycles after the beginning of the simulation. Panel (b), in turn, shows that insurance uses fall as agents adapt their strategies.

Panel (c) shows banks' capital adequacy ratio. First, it is clear that market discipline guides banks strategies toward safer levels. Comparing panels (c) and (a), we can see that bank runs fall as banks raise their CAR, from what we can infer that banks adapt strategies in order to transmit soundness to depositors. However, panel (c) also shows that, in the presence of deposit insurance, there is no more evidence of relevant depositor 
discipline avoiding risk-taking behavior by banks. In this case, banks choose much lower levels of CAR, suggesting that deposit insurance can, indeed, be associated with moral hazard.

Finally, panel (d) shows the outcome of the adoption of deposit insurance in terms of bank stability. This result suggests that moral hazard makes the system more unstable, once it removes market discipline from banks' strategies. Not only was the number of insolvencies higher, the volatility also increased, pointing to higher risk of bank failure.

This experiment's results are in line with the recent literature on the issue (BARTH; CAPRIO; LEVINE, 2004; ANGINER; DEMIRGUC-KUNT; ZHU, 2014; BENNETT; HWA; KWAST, 2015). Barth, Caprio and Levine (2004) and Anginer, Demirguc-Kunt and Zhu (2014) argue that results like ours usually involve generous deposit insurance designs, which is the case in our simulation, as deposits are fully covered. They also stress that other instruments, such as strict supervision, can reduce moral hazard from deposit insurance. Following the same line, Bennett, Hwa and Kwast (2015) argue that regulators should stimulate information disclosure of banks to promote market discipline. 


\section{Conclusion}

We have used the new agent-based model of Barroso (2014) and Lima (2014) to assess the impact of different regulation policies in the banking system. Building on an iterated version of the Diamond and Dybvig (1983) framework and incorporating bounded rationality present in the experience-weighted attraction learning scheme (CAMERER; HO, 1999), this model allows economic agents to learn and adapt their strategies according to the regulatory environment imposed by the policymaker. Thus, empirically observed phenomena such as connections in the interbank market, market discipline enforced by depositors and moral hazard in the absence of controls emerge from agents' interactions.

We then run the model to assess some current issues involving bank regulation. We begin by discussing the effects of the bank interest margin over the sector's activity and stability. This experiment shows that, while increasing banks' returns, higher interest margins lead to higher risk of bank failure and contagion. Despite not being a discussion on direct impact of regulation, this first experiment provides two scenarios to study the implementation of policies, representing different degrees of banking sector development.

We then show that the adoption of an interbank clearinghouse acting as central counterparty and requiring collateral and information disclosure from participants is successful in reducing the risk of contagion between banks. Moreover, this reduction comes at a low cost in terms of credit supply to the real side of the economy. However, it did not affect the probability of bank failure from risks other than interbank exposure.

The following experiment simulates Basel's three regulatory pillars. It shows that these policy guidelines are successful in reducing the risk of bank failure. It also shows that banks do not choose the social optimal level of capital if not regulated, supporting the rationale of capital requirements as an instrument of banking regulation, the first

pillar of the Basel Accord. However, the reduction of the credit supply is significant in this scenario, suggesting that higher stability comes at a cost in terms of the stimulus to the real economy coming from the banking sector.

Our last experiment shows that the introduction of a deposit insurance has two significant effects. On the one hand, it successfully reduces the risk of bank runs, assuring that depositors will not have losses in case of bank failures. On the other hand, the insurance triggers moral hazard, once it removes depositors' incentives to monitor banks' risk-taking strategies. Our results show that the latter can outweigh the former, leading to higher risk of bank failure.

Although we have tackled some current issues involving bank regulation, there is much room left to explore our model's full potential. Following that line, future works 
could contribute by combining regulation policies to understand how they interact. For instance, one could check the results of Barth, Caprio and Levine (2004), who stress that capital requirement is a good instrument to face the moral hazard resulting from a generous deposit insurance scheme. The model can also be used to explicitly study some of the features considered in our experiments, such as the existence of an interbank market or the central bank acting as lender of last resort (FREIXAS et al., 1999; ROCHET; VIVES, 2004). Furthermore, it can also be expanded to make possible the study of other regulation policies. One example is the introduction of liquidity constraints, such as the ones suggested by the Basel III framework (BIS, 2010).

Finally, future works could also extend our results by stressing some of the parameters - if not all of them - to study how the system reacts in extreme scenarios. For instance, one could increase the probability of deposit withdraws to set a scenario with greater liquidity risk, resulting in increased severity of the liquidity shock suffered by banks. Moreover, higher probability of default by firms could be used to study the outcomes in a scenario with greater credit risk. These are only few examples of possible stress tests that can be used to assess policy performance in times of economic distress with this model. 


\section{Bibliography}

ACEMOGLU, D.; OZDAGLAR, A.; TAHBAZ-SALEHI, A. Systemic Risk and Stability in Financial Networks. [S.l.], 2013. Cited 2 times on pages 19 and 20.

ALLEN, F.; GALE, D. Optimal financial crises. The Journal of Finance, Wiley Online Library, v. 53, n. 4, p. 1245-1284, 1998. Cited on page 23.

ALLEN, F.; GALE, D. Financial contagion. Journal of political economy, JSTOR, v. 108, n. 1, p. 1-33, 2000. Cited 2 times on pages 19 and 23.

ANGINER, D.; DEMIRGUC-KUNT, A.; ZHU, M. How does deposit insurance affect bank risk? evidence from the recent crisis. Journal of Banking $\&$ finance, Elsevier, v. 48, p. 312-321, 2014. Cited 2 times on pages 46 and 48.

BABUS, A. The Formation of Financial Networks. [S.1.], 2013. Cited on page 20.

BARroso, R. V. Modelo Dinâmico Computacional de Rede de Bancos. Master's Thesis (Master's Thesis) — Univesidade de Brasília, Brazil, 2011. Cited on page 23.

BARROSO, R. V. Avaliação de Políticas Regulatórias e de Estrutura do Mercado Financeiro em um Modelo Dinâmico de Sistema Bancário com Aprendizado. Phd Thesis (PhD Thesis) - Universidade de Brasília, 2014. Cited 4 times on pages 7, 19, 23, and 49.

BARTH, J. R.; CAPRIO, G.; LEVINE, R. Bank regulation and supervision: what works best? Journal of Financial intermediation, Elsevier, v. 13, n. 2, p. 205-248, 2004. Cited 4 times on pages $19,47,48$, and 50 .

BARTH, J. R.; CAPRIO, G.; LEVINE, R. Bank regulation and supervision in 180 countries from 1999 to 2011. Journal of Financial Economic Policy, Emerald Group Publishing Limited, v. 5, n. 2, p. 111-219, 2013. Cited on page 44.

BECK, T.; LEVINE, R.; LOAYZA, N. Finance and the sources of growth. Journal of financial economics, Elsevier, v. 58, n. 1, p. 261-300, 2000. Cited on page 39.

BENNETT, R. L.; HWA, V.; KWAST, M. L. Market discipline by bank creditors during the 2008-2010 crisis. Journal of Financial Stability, Elsevier, v. 20, p. 51-69, 2015. Cited 3 times on pages 19, 46, and 48 .

BIS. Core principles for systemically important payment systems. Bank for International Settlements, Committee on Payments and Settlement Systems, n. 43, 2001. Cited on page 34.

BIS. International convergence of capital measurement and capital standards: A revised framework. Bank for International Settlements, Basel Committee on Banking Supervision, n. 128, 2006. Cited on page 44 .

BIS. Basel iii: International framework for liquidity risk measurement, standards and monitoring. Bank for International Settlements, Basel Committee on Banking Supervision, n. 188, 2010. Cited on page 50. 
BLUME, L. et al. Network formation in the presence of contagious risk. ACM Transactions on Economics and Computation, New York, NY, USA, v. 1, n. 2, p. 6:1-6:20, May 2013. ISSN 2167-8375. Cited on page 20.

BORRILL, P. L.; TESFATSION, L. Agent-based modeling: the right mathematics for the social sciences? The Elgar Companion to Recent Economic Methodology, Edward Elgar Publishing, p. 228, 2011. Cited on page 20.

BROCK, P. L.; SUAREZ, L. R. Understanding the behavior of bank spreads in latin america. Journal of development Economics, Elsevier, v. 63, n. 1, p. 113-134, 2000. Cited 3 times on pages 19, 40, and 41.

CAJUEIRO, D. O.; TABAK, B. M.; ANDRADE, R. F. Fluctuations in interbank network dynamics. Physical Review E, APS, v. 79, n. 3, p. 037101, 2009. Cited 2 times on pages 19 and 20.

CAMERER, C. F.; HO, T. H. Experience weighted attraction learning in normal form games. Econometrica, v. 67, p. 827-874, 1999. Cited 6 times on pages 7, 20, 23, 24, 25, and 49 .

CLEVELAND, W. S. Lowess: A program for smoothing scatterplots by robust locally weighted regression. American Statistician, JSTOR, p. 54-54, 1981. Cited on page 37.

COSIMANO, T. F.; CHAMI, R.; BARAJAS, A. Did the basel accord cause a credit slowdown in latin america? ECONOMIA: The Journal of the Latin American and Caribbean Economic Association, Fall, 2004. Cited 2 times on pages 19 and 46.

DEMIRGUC-KUNT, A.; DETRAGIACHE, E. Does deposit insurance increase banking system stability? an empirical investigation. Journal of monetary economics, North-Holland, v. 49, n. 7, p. 1373-1406, 2002. Cited 2 times on pages 19 and 47.

DEMIRGUC-KUNT, A.; HUIZINGA, H. Determinants of commercial bank interest margins and profitability: some international evidence. The World Bank Economic Review, World Bank, v. 13, n. 2, p. 379-408, 1999. Cited 2 times on pages 39 and 40.

DEMIRGUC-KUNT, A.; KANE, E.; LAEVEN, L. Deposit insurance around the world: A comprehensive analysis and database. Journal of Financial Stability, Elsevier, v. 20, p. 155-183, 2015. Cited on page 46.

DEMIRGUC-KUNT, A.; LAEVEN, L.; LEVINE, R. The impact of bank regulations, concentration, and institutions on bank margins. World Bank Policy Research Working Paper, n. 3030, 2003. Cited on page 41.

DIAMOND, D. W.; DYBVIG, P. H. Bank runs, deposit insurance and liquidity. The Journal of Political Economy, v. 91, p. 401-419, 1983. Cited 5 times on pages 7, 20, 23, 29 , and 49 .

DIAMOND, D. W.; RAJAN, R. G. Liquidity risk, liquidity creation and financial fragility: A theory of banking. Journal of Political Economy, The University of Chicago Press, v. 109, n. 2, p. 287-327, 2001. Cited on page 34.

DIETRICH, A.; WANZENRIED, G.; COLE, R. A. Why are net-interest margins across countries so different? Available at SSRN 1542067, 2015. Cited 3 times on pages 19, 40, and 41. 
EISENBERG, L.; NOE, T. H. Systemic risk in financial systems. Management Science, v. 47, p. 236-249, 2001. Cited 2 times on pages 19 and 20.

ELIZALDE, A.; REPULLO, R. Economic and regulatory capital in banking: what is the difference? International Journal of Central Banking, International Journal of Central Banking, v. 3, n. 3, p. 87-117, 2007. Cited 3 times on pages 19, 29, and 45.

EPSTEIN, J. M. Agent-based computational models and generative social science. Generative Social Science: Studies in Agent-Based Computational Modeling, p. 4-46, 1999. Cited on page 20.

EROL, S.; VOHRA, R. Network Formation and Systemic Risk. [S.l.], 2014. Cited on page 20 .

EVANOFF, D. D.; STEIGERWALD, R. S.; RUSSO, D. Policymakers, researchers, and practitioners discuss the role of central counterparties. Economic Perspectives, v. 30, n. 4, 2006. Cited on page 41.

FARMER, J. D. et al. A complex systems approach to constructing better models for managing financial markets and the economy. The European Physical Journal Special Topics, Springer, v. 214, n. 1, p. 295-324, 2012. Cited on page 20.

FREIXAS, X. et al. Lender of last resort: a review of the literature. Financial Stability Review, November, 1999. Cited on page 50.

FREIXAS, X.; PARIGI, B.; ROCHET, J. C. Systemic risk, interbank relations and liquidity provision by the central bank. Journal of Money, Credit and Banking, v. 32, p. 611-638, 2000. Cited on page 19.

FUDENBERG, D.; LEVINE, D. K. The Theory of Learning in Games. [S.1.]: The MIT Press, 1998. (MIT Press Books, 0262061945). Cited 2 times on pages 20 and 24.

GAI, P.; HALDANE, A.; KAPADIA, S. Complexity, concentration and contagion. Journal of Monetary Economics, Elsevier, v. 58, n. 5, p. 453-470, 2011. Cited 2 times on pages 19 and 20 .

GALÁN, J. M. et al. Errors and artefacts in agent-based modelling. Journal of Artificial Societies and Social Simulation, v. 12, n. 1, p. 1, 2009. Cited on page 20.

GALLEGATI, M.; GIULIONI, G.; KICHIJI, N. Complex dynamics and financial fragility in an agent-based model. Advances in Complex Systems, World Scientific, v. 6, n. 03, p. 267-282, 2003. Cited on page 20.

GLASSERMAN, P.; YOUNG, H. P. How likely is contagion in financial networks? Journal of Banking \& Finance, v. 50, n. C, p. 383-399, 2015. Cited 2 times on pages 19 and 20.

GOODHART, C. A. E.; SUNIRAND, P.; TSOMOCOS, D. P. A model to analyse financial fragility: applications. Journal of Financial Stability, v. 1, p. 1-30, 2004. Cited on page 20 .

HO, T. S.; SAUNDERS, A. The determinants of bank interest margins: theory and empirical evidence. Journal of Financial and Quantitative analysis, Cambridge Univ Press, v. 16, n. 04, p. 581-600, 1981. Cited on page 40. 
HOMMES, C. H. Heterogeneous agent models in economics and finance. Handbook of computational economics, Elsevier, v. 2, p. 1109-1186, 2006. Cited on page 20.

HOOG, S. van der; DEISSENBERG, C.; TEGLIO, A. Modelling requirements for eurace. EURACE Report D, v. 2, 2007. Cited on page 20.

IYETOMI, H. et al. Agent-based model approach to complex phenomena in real economy. arXiv preprint arXiv:0901.1794, 2009. Cited on page 20.

JAREMSKI, M. Clearinghouses as credit regulators before the fed? Journal of Financial Stability, Elsevier, v. 17, p. 10-21, 2015. Cited 3 times on pages 19, 42, and 43.

KIRMAN, A. Learning in agent-based models. Eastern Economic Journal, v. 37, n. 1, p. 20, 2011. Cited on page 20.

KNOTT, R.; MILLS, A. Modelling risk in central counterparty clearing houses: a review. Bank of England Financial Stability Review, p. 162-174, 2002. Cited on page 41.

KOEPPL, T.; MONNET, C.; TEMZELIDES, T. Optimal clearing arrangements for financial trades. Journal of Financial Economics, Elsevier, v. 103, n. 1, p. 189-203, 2012. Cited on page 41.

KOEPPL, T. V.; MONNET, C. Emergence and future of central counterparties. FRB of Philadelphia Working Paper, 2010. Cited on page 41.

LEBARON, B. Agent-based computational finance. Handbook of computational economics, Elsevier, v. 2, p. 1187-1233, 2006. Cited on page 20.

LEBARON, B.; TESFATSION, L. Modeling macroeconomies as open-ended dynamic systems of interacting agents. The American Economic Review (Papers and Proceedings), American Economic Association, v. 98, n. 2, p. 246-250, 2008. Cited on page 20.

LEVINE, R. Financial development and economic growth: views and agenda. Journal of economic literature, American Economic Association, v. 35, n. 2, p. 688-726, 1997. Cited on page 39.

LIMA, J. I. A. V. Um arcabouço computacional para estudo do setor bancário através de modelos baseados em agentes. Master's Thesis (Master's Thesis) - Univesidade de Brasília, Brazil, 2014. Cited 5 times on pages 7, 19, 23, 37, and 49.

NACEUR, S. B.; KANDIL, M. Basel accord and lending behavior: Evidence from mena region. Available at SSRN 1018747, 2007. Cited 2 times on pages 19 and 46.

POUGET, S. Adaptive traders and the design of financial markets. Journal of Finance, v. 62, p. 2835-2863, 2007. Cited 2 times on pages 20 and 25.

REPULLO, R.; SUAREZ, J. Loan pricing under basel capital requirements. Journal of Financial Intermediation, Elsevier, v. 13, n. 4, p. 496-521, 2004. Cited on page 45.

ROCHET, J.-C.; TIROLE, J. Interbank lending and systemic risk. Journal of Money, credit and Banking, JSTOR, p. 733-762, 1996. Cited on page 19.

ROCHET, J.-C.; VIVES, X. Coordination failures and the lender of last resort: was bagehot right after all? Journal of the European Economic Association, Wiley Online Library, v. 2, n. 6, p. 1116-1147, 2004. Cited on page 50. 
ROTH, A. E.; EREV, I. Learning in extensive-form games: Experimental data and simple dynamic models in the intermediate term. Games and Economic Behavior, v. 8, p. 164-212, 1995. Cited 2 times on pages 20 and 24.

SAMANIDOU, E. et al. Microscopic models of financial markets. [S.l.], 2006. Cited on page 20 .

TEMZELIDES, T. Evolution, coordination, and banking panics. Journal of Monetary Economics, Elsevier, v. 40, n. 1, p. 163-183, 1997. Cited on page 20.

UPPER, C. Simulation methods to acess the danger of contagion in interbank markets. Journal of Financial Stability, v. 7, p. 111-125, 2011. Cited 2 times on pages 19 and 20.

ZAWADOWSKI, A. Entangled financial systems. Review of Financial Studies, v. 26, n. 1, p. 1291-1323, 2013. Cited on page 20. 